\title{
Innovation policy and international relations: directions for EU diplomacy
}

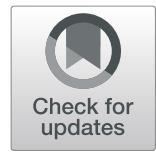

Jos Leijten(10)

\begin{abstract}
This paper explores how innovation becomes an increasingly important topic in international relations, with a deep impact on collaboration as well as on competition between countries. It analyses how certain key patterns of techno-economic change lead to changes in the global distribution of innovative activities around the world and how this affects the institutions for global governance. It outlines three near-future scenarios of the international politics of innovation. The first, called "populism and protectionism", describes an international environment which is dominated by populist and nationalist tendencies. The second outlines the approach of "innovation as a global public good", in which everybody benefits, and global collaboration is the dominant model. The third scenario combines a few innovation forces in society, which can be captured as "bottom-up innovation". These scenarios are then brought together in a single framework in which international dimensions of innovation policies that relate to a specific scenario can be mapped. In a next step, the potential consequences for international relations and innovation diplomacy are presented. The final paragraph discusses what Europe can and should do in its external relations to provide adequate answers to the forces outlined in the three scenarios. It results in a vision, which is based on the combination of four policy directions. Together, these offer a framework for aligning the different stakeholders, at the local, regional, national and European level.
\end{abstract}

Keywords: International relations, European Union, Innovation policy, Diplomacy, Techno-economic trends, Scenarios

\section{Introduction}

The second half of the twentieth century was a period of steadily growing globalization of firms and economies. With the rise of new and cheap means of communication (fax machines and later the Internet) and changes in transportation (e.g. containers) since 1980, it became increasingly easy to coordinate global activities in production and in trade [1]. Europe benefited from this globalization by amassing a large trade surplus. ${ }^{1}$ Globalization was generally seen as beneficial for everybody. Optimisation of industrial production at a global scale created huge growth opportunities in South-East Asia, China and South Korea. The flow of cheaper products to Europe and the USA contributed to increasing living standards in these regions as well.

Science and innovation were at the same time drivers and followers of the globalization of production and trade. Drivers, because they helped to create the

Correspondence: josleyten@gmail.com

Joint Institute for Innovation Policy, Pleinlaan 9, 1050 Brussels, Belgium technological and business conditions for globalization, and followers, because large companies started to bring research activities and laboratories to the countries where they already had major production centres and because universities and public research organizations internationalized their activities.

Politics and policies generally helped to improve the conditions for these globalization processes, by signing bilateral and multilateral cooperation agreements, by aligning their ownership, trade and tax policies (the WTO was an important forum for this), and by offering generous support for exports, foreign direct investments and for attracting highly qualified expats.

Rather suddenly, the picture changed. Between 2000 and 2005, China and Russia, after a period of internal orientation, became more self-aware actors in international politics. Populism grew in Europe and the USA. Following the financial crisis in 2008, foreign direct investment, which had grown from $4 \%$ of global GDP in 1990 to $23 \%$ in 2007 , fell to just $6 \%$ about 10 years later. 
For the last 5 years, growth in trade barely outpaced global GDP growth [2]. The rise of populist politics in Europe and the USA, and to a somewhat lesser extent in Asia, has changed the political discourse about globalization and related policy actions completely. In the West, globalization is seen as the cause of many problems, like job insecurity, growth of low-income jobs or no jobs at all, unwanted migration and migratory labour and a general lack of opportunities to improve one's living conditions. The latest implication (mid2018) is an outright trade-war started by US President Trump based on "America First" thinking and attempting to reduce the huge US trade deficit. Some of these developments and their possible causes and implications will be dealt with later.

For now, it is important to note that the rather sudden change in the political-economic climate has left the world of science and innovation in a state of disarray. For 30 years or more, the almost automatic trend was internationalization. Universities had started to source their professors and students from all around the world and started to send them out all over the world. Policies fully supported this. If questions were asked, they usually only had to do with rather specific security issues (e.g. the rights of access of Russian or Iranian students in Western research organizations) or with the tuition fees foreign students had to pay. Innovation, and certainly the diffusion of innovations, was often thriving on access to foreign research and on access to foreign markets. International collaboration was the evident mechanism.

Over the past 10 years, the economic and political environment for science and innovation changed completely. Self-interest of nations and competition between countries has become important in politics. This is particularly hard for the world of science and innovation, because they never conceived their role in a zero-sumgame, in which you only have winners and losers. Instead, science and innovation were believed to contribute to expanding knowledge, to creating opportunities for new products, services and markets. As long as everybody could be part of this game, everybody would be a winner, benefiting of the growth of markets, economies and living standards.

Some people would argue that science and innovation have always been part of the competition between firms and nations and that fiercer competition will only move them higher on national and international strategic agendas. Others may think that science and innovation can be rather independent forces in society that may even help to curb some of the worst effects of protectionist thinking about competition (see for example [3]) or that science and innovation can help to develop the powers to unite nations around themes that require joint action (e.g. clearing the oceans of plastics or solving the problems of water shortages).

This paper focuses on how foreign policies and diplomatic actions influence innovation and how innovation policy becomes part of foreign policies and diplomacy. ${ }^{2}$ More specifically, this paper will first address the key driving forces that contribute to the growing importance of innovation and innovation-related policies in international relations and diplomatic practices (the characteristics of dominant technological developments, the changing economic geography of the world and the role of institutions of global governance). It will then discuss possible future directions in three scenarios (protectionism, innovation as a global public good and bottom-up innovation). Each of the scenarios will give rise to specific (innovation-related) foreign policies. A few concluding paragraphs will discuss the overall outcomes of the scenario exercise and potential implications for future diplomatic actions. The paper finishes with a paragraph that addresses potential European responses to these developments and a set of policy principles to guide future EU foreign policies.

\section{A few key concepts:}

Traditionally, innovation encompasses the development and implementation of new products and processes. More recently, also new forms of marketing and organization have been added to the definition of innovation. In such a definition, innovation should be conceived as the result of a complex interplay of economics, technology and, not to forget, institutions [4]. Innovation policy has the intention to create and strengthen the institutions and capabilities that are important for innovation. With innovation diplomacy, we mean those diplomatic actions which are generally meant to contribute to fostering innovations in international relations. But for many different reasons, also trying to protect innovations in the own country or delaying their diffusion may be part of innovation diplomacy. Defined like this, innovation diplomacy is part of the set of national (or sometimes also international) innovation policy instruments. Such innovation policies are usually closely linked to or embedded in foreign economic policy and trade policies. But other policy areas, such as social policies, energy policies and environmental policies may be just as relevant.

\section{A word on approach:}

This paper is the result of extensive desk research, mostly literature analysis. Scientific literature on the issue is scarce: the concept of innovation diplomacy is still "under construction" [5, 6]. Innovation diplomacy is 
being shaped in close connection with the rapidly changing international political environment of today. Part of this paper is a scenario analysis, which should be read as a thinking-exercise to explore the forces that contribute to the shaping of the future of the innovation policy as part of foreign policy and of the related diplomacy activities. The scenarios reflect the changing political environment and are used to refine the concept and the analysis of the practices of innovation diplomacy. In that sense, the paper is an effort to outline the thinking that is needed to come to grips with the complexities of innovation policy in international relations.

\section{Patterns of techno-economic change}

Without any doubt, information and communication technologies (ICTs) are the most transformative technologies of the past 50 years. Technological developments have driven the costs of communication and processing of information down while at the same time improving on speed and processing capacity. In the process, demand for their key enabling technologies has grown at a very fast pace. This holds for networking (e.g. speed, capacity, mobility, accessibility), processing (again speed and capacity but also size and weight) and capturing data (sensoring, measurement) and for storage of information. This has contributed to ICTs becoming ubiquitous, entering all sectors of society and (almost) all aspects of personal life [7]. ICTs are also playing a key role in other fields of technology (e.g. nano-, bio- or environmental technologies), determining their speed of development and characteristics of applications. Most influential are two developments which both have firm anchors in the basic technologies. The first is networking of almost all aspects of life, and the second is availability of data. ${ }^{3}$

\section{The networked society}

Over the past decades, demand for fixed and mobile networking and related devices and services has exploded. Developments in networking were partly driven by the growing demand for mobility. Processing did rather closely follow Moore's law, ${ }^{4}$ despite predictions that it was nearing its boundaries. Networking and information storage also experienced exponentially improving performance. Developments over the past 15 years were to a large extent inspired by the "ambient intelligence" vision. This vision of seamlessly integrated ubiquitous computing will remain important over and (most likely) beyond the next decade [8]. Demand for faster and more flexible networking, mobility, processing and storage capacity will continue to increase at exponential pace, mainly because it allows doing things easier, faster, simpler and at lower cost. New types of applications building on machine-to-machine communications (e.g. self-driving cars), Internet of things, autonomous robots, new display and interfacing technologies (including virtual reality, augmented reality and telepresence), artificial intelligence, speech and language processing, etc. will add to this increasing demand.

In view of the expectation that, at a certain point, Moore's law will reach its limits, alternatives are and have been explored, such as the use of new nanofabricated materials (e.g. nano-tubes, graphene), optical or photonic processing, quantum computing and biocomputing. Each of these builds on a specific technological approach, and so far, none seems to be capable of large-scale replacement of current semiconductor technology. However, important niche markets might be targeted in the next 10 to 15 years. With a growing interest (for medical applications first) in linking computing power with (human) living cells in biological and neurological processes, further development of the principles of biocomputing would appear important. All these new technologies potentially contribute to further spreading the logic of networking and information to new societal and personal domains.

On the networking side, increasing speed and capacity are also very important. But the main technological challenge continues to lie in safe and seamless communication between networks of different nature (fixed and mobile). The widely shared vision of future developments is that of highly flexible configurations of a "network of networks". In other words, everybody and everything can (and should) be connected.

\section{The data society}

Next to networking, a second feature of ICTs has become a dominant force in society: the capabilities of making data available and accessible, and of analysing them in such a way that they can be presented as sensible information. Nowadays, all kinds of human and non-human processes leave behind an enormous trail of data. Production processes in industry are, for example, monitored by numerous sensors that measure temperature, pressure, size, colour, and whatever else that can be monitored at many times per second. Our payment behaviour is monitored by shops (via loyalty cards), banks and credit card companies. In addition to the phone-companies, producers like Google, Apple or Huawei can see in great detail where we go with our mobile phones. The same is true for the new generation of connected cars, which can be followed and monitored by the producers and an unknown (for the owner) number of service providers (e.g. digital radio, navigation, road management). While this may seem rather technical, recent discussions around Facebook and the new European rules for data protection (GDPR) have revealed the amount of data that we ourselves 
(deliberately or completely unconsciously) leave behind when posting messages, pictures, etc. for known and unknown people and organizations. This has grown to proportions beyond comprehension.

When presidents are talking about how Artificial Intelligence will determine the future and advocate a competitive position in the field (e.g. Russian President Putin in September 2017 or French President Macron in 2018), it is clear that the data society is far from mature. Data-gathering, processing and analysis are expected to make major steps forward in the coming years, mainly through increased data-collection (e.g. the internet of things), better data availability, increased computing capabilities and possibly also through the development and use of new automated learning systems and analytical algorithms (Artificial Intelligence). Commercial applications will create new business and new jobs, but they will also destroy millions of others, almost certainly not in the places where the new businesses and jobs are created. This may lead (again) to a disruption of relatively stable relations between countries.

\section{Technology and its impact on international relations}

The further development of networking and the growth of data will be accompanied by several societal challenges. Some of these challenges will be highly political (Who has access to what? How open or closed and dedicated will the networks be?) and may undermine the openness that has driven internet developments over the past decades. Trust will become an increasingly important issue, certainly when we start to depend on machine-to-machine communication. Networked technologies, their applications and the underlying data- and information systems have become vital for the basic functioning of society and, in many cases have also become vital for our personal lives. But they have also led to changes in the structure of economy and society.

Generally, the economy of networks is characterized by so-called network externalities, which means that the higher the number of members/participants in a network, the higher the value of the network for its members/participants will be. This is true for a simple telephony network, but also for the internet and the diversity of applications that make use of it. It leads to strong tendencies towards "winner takes all" mechanisms. Examples of today are the Google search engine, Google's Android, Amazon, Facebook, AirBnB, etc. ${ }^{5}$ The mechanisms behind the formation of such virtual monopolies were already extensively analysed and described 20 years ago (see for instance [9]). But politics and the public debate are only gradually starting to become aware of the implications of the rise of such (almost global) monopolies or oligopolies [10]. The debates are heating up about the market power of these global companies in their roles of platform, gatekeeper or intermediary, about the way they transfer profits (so far mostly to Silicon Valley), avoid taxation and social or housing policy regulations (e.g. Uber and AirBnB), and generally try to benefit from competition between countries and regions for jobs and other benefits [11].

One of the key issues for international relations is that technological power (and the related social, political and economic power) is not evenly distributed around the globe. Such powers are concentrated in innovation ecosystems, hubs, clusters or megaregions, to mention just a few of the terms that are used in the literature to describe geographical concentrations of technological power. The combination of networked technologies and data leads at the same time to a stronger concentration of powers and to a deeper penetration of these powers into economic, social and political life. In many countries, this is a reason for putting technology higher on the political agenda. But when this happens, we can also observe great differences in the way national policies want to regulate technology-based power. Even in the single European market, we can see major differences in the ways in which, for example, Uber and AirBnB are regulated. The regulatory differences may become even bigger when so-called ethical issues start to play a role (e.g. in relation to embryonic stem cells) [12]. These developments contribute to the growth of an international field of negotiated collaboration or, in some cases, outright competition.

One could argue that these issues need to be handled within the bodies that are often specifically set up to discuss and find agreements on the international dimensions of business, trade, taxation, social policies, etc. (e.g. WTO, OECD, ILO, etc.). But apart from the fact that not all relevant countries are members of these organizations or subscribe to the agreements and rulings, there is another international dimension which needs to be considered. In a society that gradually becomes dominated by networking and data, the speed of innovation and its transformative impact on business, jobs, government, tax income, etc. is increasing. With innovation becoming more important for countries to gain a competitive edge, it is also becoming an increasingly important aspect of international relations (see also the short account in [5]). This may go well beyond the sphere of economic competition into the domain of politics. A recent example with potentially far-reaching consequences is the growing evidence that countries interfere in each other's elections by manipulating social media or (try to) disrupt essential services through intrusion into vital information systems. At the very least, these examples point to the directions that potential innovations in (international) conflict may take [13]. 
The newer ICTs with their focus on blockchain, artificial intelligence, quantum computing, robotics, 5G mobile, etc. will most likely contribute to a further strengthening of the winner-takes-all forces in networking and lead to further opportunities to exploit data. An example in case is that the claim on decentralization of blockchain technology, even with some political support [14], cannot be fulfilled in the case of Bitcoin, what is still its major application. Capital requirements and scale effects have in 10 years led to a considerable concentration of Bitcoin mining and ownership. In theory, the sector might develop completely different economic and business models, but therefore strong government enforced regulation is necessary. But governments are reluctant and/or incapable to develop such regulation in view of the absence of an internationally shared vision.

\section{International relations and geography of innovation}

New technologies are thus putting innovation more firmly on the international agenda. Of course, issues of technology catch-up and capacity building still play a major role in international relations, in particular for developing and/or lagging countries, ${ }^{6}$ but, with the globalization of networked technologies, as was described in the previous paragraph, these networked technologies themselves, their applications and the people and organizations that use them in all domains of society, have become one of the prime factors to drive changes in foreign relations and in foreign policies around the world.

And there is more. The technologies that helped to build global networks have done their work so well that the global value chains that were mostly built over the past 30-40 years have now reached maturity [2]. It has become difficult to find further efficiency gains by splitting production processes in ever smaller parts that each benefit from favourable conditions in specific localities. The maturity of value chains contributes at least partly to improving the conditions for re-shoring (e.g. bringing production back from China to Europe or the USA) [15]. As the massive off-shoring of production to China is a factor that drives current populist and nationalist tendencies (more so in the USA than in Europe), the fact that it has become difficult to find further efficiency gains by another relocation may very well make the call for re-shoring more realistic than it was 15 years ago. Re-shoring may also be helped by the further penetration of ICTs in the core of production processes through new technologies such as on-demand-production and/or 3D-printing. However, re-shoring does not automatically lead to growth and a stronger competitive position. Therefore, it should be firmly based on innovations. Indeed, very often re-shoring goes together with a higher capital intensity, with higher levels of automation and with fewer jobs, to counter-balance for lower wages and other advantages elsewhere.

In other words, innovation is needed to build stable and growing value chains and economies when other advantages, like low wages or specific geographical conditions, are no longer available or have become less important. This adds to the importance of innovation in the competitive behaviour between countries. It is no longer only a question of who has the strongest companies that can export their products and services: what increasingly matters is the strength of national and/or regional innovation systems. The geography of innovation has become important in reshaping foreign relations. In the following lines, this will be illustrated with the case of the changing EU-China relationship in photovoltaics, drawing on one of the case-studies of the EL-CSID project.

\section{The case of the EU-China relationship in photovoltaics}

Until the year 2007 approximately, the European solar PV industry was in a leading position, with a global market share of around $30 \%$. One of the reasons for the strong PV production was, amongst others, strong demand-side policies in various European countries. These were started by the German government, which introduced a very attractive guaranteed feed-in tariff for electricity generated by privately owned solar PV installations in 2000. Similar measures in other European countries followed shortly after. This, together with steadily decreasing costs for solar PV modules, led to an unprecedented surge in demand. For a number of years, the majority of this demand was fed by European produced PV modules. On this basis, the European solar PV industry was booming.

The situation changed relatively suddenly due to a combination of various factors and events. First, a shortage of polysilicon, the key raw material for solar PV cells, arose in 2004 and lasted until 2008. This meant that European manufacturers were obliged to procure polysilicon at very high prices, which obviously inhibited them from making investments in the upgrading (size- and/or technology-wise) of their production capacities. At the same time, the situation was very different in China. Helped by high foreign direct investments, Chinese companies were able to make significant investments in the increase of their production capacities. But not only this, they also invested in IP (in the form of patents) of established manufacturers in Europe, as well as in an increase in their own R\&D activities. 
When the polysilicon shortage ended in 2009, Chinese production could go full steam ahead and fill a large gap between steeply increasing European demand on the one hand and the only slowly increasing European production on the other. This gave Chinese producers the chance to prove the quality of their products and to show that there was no substantial difference compared to European products. Some of the European producers were also still bound to so-called "take-or-pay" contracts for polysilicon, which they had entered during the period of polysilicon shortage. This meant that they had to continue buying polysilicon at high prices or pay fines, whereas other competitors, in particular new entrants from China, were not exposed to this constraint. A third factor started hitting European producers on their home markets, which was the fact that, as a consequence of the financial crisis, several governments significantly reduced or completely withdrew favourable feed-in tariffs or even introduced retroactive taxation, which reduced demand significantly.

In 2008, China overtook Europe in terms of production output and sales worldwide. All these developments led relatively suddenly from a global undersupply to an oversupply, resulting in strong price cuts. ... Chinese companies had access to substantial debt financing deals and loan guarantees from 2010 onwards, which helped them to sustain themselves and to grow production capacities even further. The price of Chinese solar PV panels, with which European producers could not compete, eventually led to EU anti-dumping duties on Chinese solar panels in June 2013. In August of the same year, an agreement was reached that limited the imports of Chinese solar panels and set a minimum price.

However, ... at this point the European PV industry had already "lost the battle". By 2014, Chinese producers had reached a share of global production of $69 \%$. While in 2004, five out of the world's top 10 producers of solar PV panels were European, not a single European producer remains in that list today, with very dramatic consequences in terms of European jobs: according to an estimation by Ernst \& Young together with Solar Power Europe, 59.000 people were employed in solar PV production (upstream only), of which only remained 15.000 in 2014 [16, 17]" ([18], pp., 5-6).

The case study concludes that although China generally is a major collaboration partner in the European Horizon 2020 programme, there have been changes that can be directly related to the solar PV experience described above. In the first place, there are no recent research collaborations with Chinese actors in the field of solar PV. In the second place, interviewees indicate that collaborations in other highly competitive fields also seem to be declining. On a more general level, the case study concludes that it is useful to make a distinction between general scientific collaboration actions and innovation-based collaboration or competition in international relations and diplomacy.

The solar PV example may lead to the simple conclusion that seeking cooperation in highly competitive fields is not the preferred option. This may be true in the specific case discussed above, for example because the EU has enough technological knowledge and innovation capabilities in the solar PV field, but it cannot be a general rule. The technological expertise and other capabilities needed for innovation are often so complex (e.g. the need to bring different fields of technological expertise together), and the costs of innovation have become so high that collaboration is a necessity. In addition, there are many problems that drive demand for innovations that are not confined to the borders of one country. There is a by now well-known series of global challenges, like climate change, food and water supply, health and security issues, that need a collaborative approach between a larger group of countries. It is not only that the problems simply surpass borders, but also that the solutions will in most cases require complex systems of collaboration across borders. Again, this complexity raises the costs of the necessary innovations.

Production plants, logistic facilities, offices, jobs and even research and testing facilities are the most visible parts of companies. But competitive pressures and the growing difficulties in exploiting comparative advantages like low wages have led to the growth of a much less visible part of what companies do. Next to physical assets like buildings and machines and labour assets (including skills), an increasingly important part of what companies do is related to their financial assets. Differences between countries may in some cases be rather straightforward, like the seemingly abundant availability of venture capital for high tech start-ups in Silicon Valley or direct state support in China (generous government backed loans or the much-discussed exchange rate of Chinese currency). Other cases are more complicated and less easy to see, like companies benefiting from differences in tax-rules (e.g. putting intellectual property assets in one country with favourable conditions and registering profits in another). Developing the new mechanisms to either lower or avoid taxation should be seen as a highly innovative activity which may include the reshaping of the formal structures of a company and its profitability. Recently, these practices have come under the scrutiny 
of governments around the world, much helped by investigative journalism and reporting based on for example the Panama Papers and the Paradise Papers (see for example [19]). Financial practices also became a regular part of foreign economic policy when governments started to use their tax-regimes to create a more favourable location for global companies. In very similar ways, companies sometimes try to benefit from differences in labour or environmental government regulations, but recently, the public and political debates are changing. Certain practices seem to become less acceptable, in the first place, those of companies that design highly complex structures to avoid taxes and, in the second place, those of governments that allow these structures.

Through such policy practices, innovation in companies is partly becoming dependent on government regulations. And the other way around, company practices lead to political debate and political intervention mostly through the design of new regulations. The European Commission is trying to fine the likes of Google and Apple for presumed monopolist or anticompetitive behaviour. Tax evasion has become subject to gradually sharpening rules, nationally and internationally. The way personal data (another set of intangible assets) is collected and used for commercial purposes has led to adjustments in data and privacy regulations in Europe. These developments in tax policies, in competition policies or in privacy policies are all strongly related to technological development and innovation. Mostly implicit, technology and innovation are thus becoming more important in the competitive behaviour of countries and thus become part of foreign economic policies.

\section{Institutions of innovation: global governance and new players}

Chris Freeman [20] defined the concept of systems of innovation more than 30 years ago as the "network of institutions in the public and private sectors whose activities and interactions initiate, import, modify and diffuse new technologies." With this, he drew attention to the existence and role of the range of institutions which are important for innovation. This includes educational and public research institutions, public and private support mechanisms for developing and funding innovations in different stages of their development (different consultancies like technology, human resources, marketing, design and financial; dedicated support for start-ups, often in a mixed public-private setting; public and/or private loan facilities; IPR-support).

Technological systems based on fields such as ICT, nanotechnology and biotechnology have become increasingly complex. Enterprises can no longer manage and afford to mobilize internally all the resources and competences needed for innovation. Innovation today increasingly depends on external sources, networks and collaboration (open innovation). Innovation is becoming "systemic", i.e. dependent on the interplay of many different players and forces. The "systems of innovation", or following Freeman, the networks of institutions, have become both actors in the international arena as well as object of innovation oriented foreign economic policy. In the process, many international organizations have been established to handle the international dimensions of innovation, often as part of a broader mission. Also, existing organizations took issues of innovation on their agendas.

Roughly, until 2010, there was an atmosphere of optimism about the power of institutions like WTO and other UN-related institutions, OECD, G7/8 or G20, and a number of trade agreements covering larger numbers of countries, like TPP around the Pacific and TTIP between Europe and the USA, to help build a "global innovation economy" in which innovations could be developed and diffused in level playing fields and where needed and/or useful in a collaborative atmosphere [21]. The new products, processes and services offer solutions for pressing (global) problems and generally contribute to rising productivity and increased wealth for all. An earlier publication [5] briefly showed that (technological) innovation had become an important topic on the agendas of many international organizations and networks. These organizations and networks helped to foster innovation thinking and building the right institutions and policy instruments, mostly based on what can be found in leading countries in the field. For a series of different reasons, the global institutions are getting weaker [22]. But a number of leading countries in the field of innovation and policymaking, including the European Union, have set up collaborative programs to help build the institutional frameworks for innovation in many developing and innovation-following countries around the world. One of the case-studies of the ELCSID project specifically addressed the collaboration for strengthening innovation capabilities with Latin America and the Caribbean. ${ }^{7}$

\section{The case of EU - Latin America and Caribbean collaboration}

Latin America and the Caribbean countries' (LAC) and the European Union's (EU) cooperation on science, technology and innovation has a long history based on cultural roots and common concerns. They share a strategic bi-regional partnership, which was launched in 1999 and stepped up significantly in recent years. The two regions co-operate closely at international level across a broad range of issues and 
maintain an intensive political dialogue at all levels" [23]. "EU-LAC relationships are moving from a traditional cooperation model towards a learning model, where sharing experiences and learning from innovations appear to be decisive [24].

The EU-CELAC cooperation in STI is strong at different levels and enjoys political support. Although the cooperation has a long history, mainly based on cultural roots and common economic interests, the cooperation in STI is more recent and dates back to 2010, when the EU-CELAC Summit agreed on establishing the first EU-CELAC Action Plan that included a concrete chapter dealing with STI. ... , several EU-funded projects and programmes are evidence of the strategic tools in place to support the dialogue, such as international cooperation activities under the European Framework Programmes (FP7, H2020), AL-Invest, INCO-NET, ALCUE NET, ERANET-LAC, EU-LAC HEATH, ELAN, ALFA Latin American Academic Excellence, COSME, the Bilats with Mexico, Argentina, Chile and Brazil, LAIF - Latin America Investment Facility, ELAN Network, etc ([25], p., 20).

The cooperation actions serve a large number of different goals. From the perspective of Europe, they are part of a broad set of actions to build stable political and market relations between LAC countries and Europe. As Selleslaghs observes: "The European Union (EU) has adopted a very generous region-toregion approach towards Latin America in recent decades. ... An ... interesting case of EU-driven interregionalism is the case of EU-Latin America science diplomacy. In this policy area, it seems that the EU's interregional approach has been particularly successful, as both regions continuously call for the creation and strengthening of a "Common Area for Higher Education, Research and Technology" and various high-level working groups and action plans have been established to achieve this end" ([26], p., 2). It appears that the interest from the side of Latin American countries in collaborating with Europe is only growing now that the presidency of Trump is contributing to a stronger US-aversion. But the specific science and innovation-oriented actions go deeper and concern, for example, the transfer of the European approach towards sustainable development, creating a framework for raising competitiveness of companies with open innovation types of cooperation, collaboration based on mutually beneficial effects in specific technologies (e.g. bio-economy or solar energy) ${ }^{8}$ or the transfer of the European model for regional smart specialisation policies. Whether intended or not, the outcome of the specific actions may lead to greater similarities in innovation-related policies and institutions, which most likely ease further collaboration.

This example shows how institutions can be the intended outcome of collaborative programs, but, in a next stage, also can become drivers for further collaboration. In addition to such state and supra-national state actions the field of innovation and innovation policy globally has been going through a period of 10 to 15 years of rapid rise of new groups of actors and institutions at local and regional levels. Theoretically, this is reflected in the thinking about clusters, agglomerations and regional innovation ecosystems, in which spatial and other forms of proximity of a wide diversity of interrelated innovation actors are important factors for growth. ${ }^{9}$ The European Commission formalized this process around 2012 in its so-called smart specialization strategy, which basically requires all regions to develop a selective strategy with regard to innovation. The strategy builds on existing and newly established local and regional innovation institutions. Some are mostly industry driven (e.g. Brainport Eindhoven). Others are dominated by the presence of a large and strong university (e.g. the Cambridge Cluster). Some are highly formalized organizations, others operate more as loose networks. But in all cases, international collaboration and competition, linked to the value chains that dominate the region, have become important in their functioning and operations. The institutions develop activities to define their international priorities and send out delegations (often of mixed public and private composition) to regions which are of interest for further collaboration or are seen as (potential) competitors. It effectively leads to the growth of a new group of actors in the fields of foreign economic policy and innovation diplomacy. This new group is not necessarily following the lines of national foreign policy but may very well have its own goals. For example, states in the USA are trying to figure out whether Trump's policies are beneficial for them or not. But it is difficult to generalize. It might also be very rewarding for a region to be well embedded in national policies. The picture is further complicated by the fact that there may be considerable sectoral differences (e.g. agriculture vs industry or services) in perceived impacts.

\section{Scenarios}

In the post Second World War period, economics, science and innovation were characterized by increasing globalization and openness. The World Trade Organization has successfully pushed free trade and the removal of barriers for access to markets around the globe. International science, technology and innovation organizations have worked hard to build joint agendas. 
Developments gained speed after the fall of the Berlin Wall and the collapse of the Soviet Union. Countries that were known for their barriers to market access, like China, Brazil and Iran, have become sensitive to pressures to open-up. And even the poorest of countries in Africa seem to benefit with growing economies, wellbeing and wealth. We were getting used to increased free trade, global collaboration, openness and shared ambitions.

Over the past decades, the changing landscapes of research and innovation have been the subject of studies and debates. ${ }^{10}$ Some of these studies were focused on developments in the nature of research and innovation processes themselves and other studies tried to capture changing global patterns (e.g. the internationalization of universities and business $R \& D$ and/or the rise of China). In several cases scenarios were developed [27-30]. Most of these scenarios build on ongoing internationalization and recognize the force of bottom-up movements. The most recent scenarios also recognize forces which may lead to increasing fragmentation (in Europe or in a multipolar world). For many people, however, in Europe and the USA, but also in Asia, globalization has been stretched too far and an increasing number of them feel "left out" of the advantages it brings. Unemployment, poverty and insecurity are blamed on "the foreigners". With growing populist politics, national (and regional) self-interest is growing and with it are competition and powerplay between nations. The consequence so far is mostly seen in the debates about how to react to this new political reality. Such debates touch upon all areas which are relevant for innovation, such as trade policies, the freedom and trustworthiness of the scientific community, protection of intellectual property rights and "industrial secrets", and even the field of higher education. About the latter, Altbach and de Wit make the following observation: What one might call the era of higher education internationalisation' over the past 25 years (1990-2015) that has characterized university thinking and action, might either be finished, or be on life support. .... Trumpism, Brexit, and the rise of nationalist and anti-immigrant policies in Europe are changing the landscape of global higher education. We are seeing a fundamental shift in higher education internationalisation that will mean rethinking the entire international project of universities worldwide [31].

The following paragraphs will explore the potential consequences of this change for foreign economic policy and innovation diplomacy. Three scenarios will be elaborated and discussed. They are derived from the analysis of the forces of technological development and political economy as outlined in the previous three paragraphs and from analysing earlier scenario efforts. The first scenario reads as a direct reaction to the combined populist and nationalist tendencies and is called "populism and protectionism" (Table 1). The second can be read as a continuation of the strong internationalization forces of the recent past, in which innovation and growth are there for the benefit of all. In this scenario, innovation is a global public good, which also provides the title of the scenario. The third scenario builds on a diverse set of strong societal and technological tendencies, which share the characteristic that they develop relatively independent of national research, technology and innovation policies. This scenario is driven by the strength of networking externalities and the resulting push for globalization in many of the new technologies of today and the foreseeable future. And it is driven by the consequences of user-driven innovations in sustainability development, urban development, employment and other fields. This scenario is called "bottom-up innovation".

Each of the scenarios will be outlined. The focus will mostly be on describing the forces leading to the emergence of the scenarios and less on describing the resulting futures. This will be followed by an exploration of the possible consequences, first on economy and innovation and in a second step on foreign policy and innovation diplomacy. The scenarios do not intend to describe what will happen, but rather to explore what may happen when a specific force or tendency becomes dominant. In the real world, all three forces or tendencies will be present at the same time in a more or less strong degree.

\section{Scenario 1: populism and protectionism}

The first scenario is a direct response to the populist and nationalist tendencies in politics. It foresees a world in which nations and regions try to protect and if possible to expand their perceived existing industrial and cultural strengths and will try to preserve perceived societal achievements. Critical science is not welcome. Innovation is often seen as threatening existing jobs and social relations. The general orientation is inward and most populist politicians see international collaboration as a burden rather than as something beneficial. Economic growth is expected to slow down, and international business operating in global markets will face resistance.

Much has been written about the background of populism and related nationalism. Most authors seem to agree that the prime factor behind these tendencies is that many people feel left out or disadvantaged by the processes of (economic) globalization and seek to restore control over their own environment. ${ }^{11}$ Processes of globalization of production in practice meant the displacement of relatively well-paid industry jobs to China and other countries. Rising income inequalities were an 
Table 1 The differences between populism and progressivism (source: ITIF, ([32], p., 2)

\begin{tabular}{ll}
\hline Tech populism & Tech progressivism \\
\hline Appeals to emotion & Appeals to reason \\
Motivated by self-interest & Motivated by societal benefit \\
Distrusts the system & Trusts the system \\
Focuses on possible downsides & Focuses on benefits of progress \\
Distrusts government and business & Sees business and government as extensions of collective action benefiting society \\
Sees problems as "us versus them" & Sees problems as opportunities to work together \\
\hline
\end{tabular}

almost direct result of this process. Populism usually goes together with strong disapproval of the political establishment (the traditional parties) and distrust of the traditional business elite. "Today populism spans a wide gamut of political movements, including anti-euro and anti-immigrant parties in Europe, Syriza and Podemos in Greece and Spain, Trump's anti-trade nativism in the U.S., the economic populism ... in Latin America, and many others in between" ([33], p., 12). It is important to note that the difference between populism and progressivism does not follow the known right-left distinctions in politics. Both the political left and the political right have their populist strands. On the left, it is often about restricting the freedom of businesses with the goal to protect employment, workers' rights, etc. On the right, it is mostly about defending existing social structures and culture against potential "intruders". Formulated like this, it also becomes clear that left- and right-wing populism often find common ground.

The impact of populism on innovation is complex and often not very visible, because it does not directly translate in clear political views on technology policy and innovation. Most common is something which might best be called "innovation aversion". It implies a general resistance against anything that transforms existing structures, and thus has a wider impact than the betterknown "risk-aversion" with its focus on "playing safe". The US-based think tank the Information Technology \& Innovation Foundation (ITIF) ${ }^{12}$ describes the distinction between what they have called Tech Populism and Tech Progressivism in the following table:

Both left and right-wing populist conservatism would thus focus most on the disruptive implications of new intermediary services like Uber or Airbnb on existing businesses in taxi-services or the hotel-sector and try to defend the status-quo. Also, the call for restrictions, in particular when foreign capital is taking control over so-called national champion companies (see for example the cases of Unilever and AkzoNobel in 2017 in The Netherlands [34]), is often sooner the result of populist emotions to protect national assets than of a deeper understanding of the possible positive and negative consequences.
This example also points to the fact that nationalism and innovation aversion often go together. ${ }^{13}$ Regionalism as it can be found in, for example, Catalunya and other regions of Spain, in Scotland in the U.K., and in several other places in Europe must be considered as a special case of nationalism. It also reflects a strong "we are better off on our own" sentiment. But it does not always translate into simple economic regionalism. In contrast, nationalism often directly translates in the erection of trade and other barriers to protect national industries against foreign competitors, hence the term "economic nationalism" [35].

The focus on protecting the national economy from foreign competition and other influences, results in defensive or protective policies like raising import tariffs on certain products, limiting scientific or technological collaboration, preventing the take-over of national "iconcompanies" by foreign investors, requiring local content to get access to markets, and many other policies. ${ }^{14}$ Such policy measures are likely to have considerable impacts on innovation. The negative effects on innovation diffusion around the world will be almost immediate. With high barriers to diffusion, countries will have to invest more to realize innovations themselves. But in an innovation averse environment it is unlikely that expenditures can be raised. So, generally, a slowdown of innovation and growth is to be expected. And this is not getting any better because of the deeper effects of protective measures on the processes necessary for the search for new innovations. An innovation averse climate and less competition (or more protection) will reduce the chances for developing new products, services and systems. And it will reduce the opportunities to bring innovations to markets, which because of the protective measures will be of smaller size anyway.

All in all, we may expect a growing pressure on foreign (economic) policy and the diplomatic services to become more defensive, certainly compared to the period which lies behind us, in which they had a strong focus on seeking collaboration agreements and alliances. If the protectionist approach is the main driver for the work of diplomatic services in the fields of economic policies, technology and innovation, they will develop a strong 
focus on identification and mitigation of potential risks to national economic and innovation interests. Their main activities will be to identify and follow in other (competing) countries the technologies and sectors which are critical for their home-country's economy. The information gathered will mainly be used to inform the development of national protectionist and defensive policies. An offensive strategy might be possible, but only when it can build on existing national strengths in a specific field of technology and in specific markets and if it does not conflict with the general attitude of innovation aversion and the related reluctance to invest in new innovative developments. At the very best, this scenario leads to a transactional approach to international relations [36].

\section{Scenario 2: innovation as global public good}

The second scenario can be read as a continuation of the strong internationalization forces of the recent past in which innovation and growth are there for the benefit of all. It foresees a global level playing field for scientific and technological cooperation and competition, driven by a strong political desire to solve global problems (e.g. as laid down in the UN Sustainable Development Goals) and by increasingly globalized markets. Seeking opportunities for innovative solutions and creating the necessary conditions (e.g. resources and collaborative organizations) will give rise to internationally oriented innovation policies.

There are two important views that underpin this scenario. The first one is the generic perspective which says that innovation builds on knowledge which is largely public and global, even if certain applications are privately appropriated and protected by patents [37]. The second perspective focuses on innovations needed to solve global problems. International collaboration is needed to build the necessary knowledge, develop the technologies and realize these innovations. The global problems perspective in this scenario will most likely get a major political push forward if some of the global problems get worse, turn into disasters, which affect many countries, etc.

Both perspectives have in the recent past led to major efforts to build international collaborations and institutions, partly with a global reach and partly with a focus on world regions, not to speak of the numerous bilateral agreements. Most of these are of public origin and nature, but not exclusively. There are quite a lot of private sector initiatives that at least partly work in the perspective of innovation as a global public good, by exchanging experiences, joint skills development, etc. The European Industrial Research Managers Association (EIRMA) which brings together the R\&D and innovation managers of about 80 leading companies, is an example of this approach. Next to fully private initiatives, there are also mixed public-private collaborations. The global challenges perspective has certainly led to a very large amount of international initiatives, covering almost all functions which need to be present in innovation systems (see par. 6 for further elaboration of the innovation system functions).

Despite the growth of populism and nationalism as the political forces which drive scenario one, there are also strong political forces to drive this second scenario. There is ample support for a continuation or even reinforcement of the "traditional" orientation towards collaboration and openness. Global problems and challenges will not disappear when self-interest becomes a dominant political driver. Climate change, pollution of the oceans, epidemic health risks and other problems will continue to call for joint action. There is a growing threat of climate change-related disasters which are not confined to national boundaries. But also threats which are the direct result of human or political actions (like nuclear and electronic warfare or the spreading of highly contagious diseases through increased international travel) remain causes of international concern and keep pushing towards international collaboration in the search for solutions. In these fields, innovation is an undisputable global public good. Especially, in a more competitive environment, however, free riders will hardly be accepted. Therefore, the pressure to engage in collaborative efforts will most likely increase. But the work of global governance institutions (UN, WTO, etc.) will become an even greater challenge than it already is. ${ }^{15}$ They will become arenas for new power-struggles, precisely because they are the institutions in which agreements can be made on how to address global challenges. The UN Sustainable Development Goals and the Paris Agreement on climate change are good examples of how difficult it is to reach an agreement between countries with different interests in different stages of development. They show how diplomatic and political pressures are used to align diverging views and how these pressures increase (successfully or not) when a country withdraws, like the USA under president Trump.

Global or international action is also undertaken by private foundations, of which the Bill and Melinda Gates Foundation (BMGF) with a focus on health and education is probably the most well-known. "... philanthropy could provide a real source of innovation in development. Without the political accountability and economic spending constraints that most donors face, ..., foundations are better placed to take on more risk and foster new approaches and partnerships." (According to Dr. Noshua Watson as quoted in the Guardian [38]). Such philanthropy comes in many different forms, from delivering relief in disaster areas to highly innovative 
solutions which help to modernize society. Of recent date is the example of the Google/Alphabet initiative to bring internet to remote Africa via a network of balloons. It is unclear whether this is philanthropy or a fully commercial project [39]. But it is certainly a long talkedabout solution for the connectivity problem in remote areas around the world. Because innovations that address global challenges are almost by definition public goods, we may expect continuing pressure on the public and on the private sector to address these challenges. A multitude of private and mixed public-private initiatives can be expected if the institutions for international governance cannot deliver.

At a national or multilateral government level, a few different models are developing and deserve further discussion. Here, we will briefly consider the cases of China, Europe and the USA. With its Open Science, Open Innovation and Open to the World approach the official EU policy is without doubt the most idealistic among the three. The policies aim at spreading knowledge as soon as it is available, opening up the innovation process to people with experience in fields other than academia and science, and promoting international cooperation in the research community [40]. Furthermore, the European Union has put a challengesdriven approach and more recently a mission-oriented approach high on its policy agenda for research and innovation. These approaches are predominantly internally oriented, but the knowledge and innovations built under these challenges (for example secure, clean and efficient energy or smart, green and integrated transport) and missions have a broader and mostly global reach. The selection of the challenges and (in the next EU policy period) of missions with specified goals will thus also guide actions in international cooperation. For this, the EU sees international institutions as vital. "In a strategic environment where we can no longer take our rulesbased order and shared values for granted, supporting global governance and the United Nations in particular will be an additional priority for the European union" [41]. In other words, the EU prefers to continue to work through the international institutions and to promote innovation as a global public good, even when it recognizes that complementary bilateral and multilateral actions might be necessary.

The USA has for many years been an important initiator and supporter of the global governance institutions. And even when the Trump administration seems to be dominated by a rhetoric of retreat and self-interest, there are abundant signs that the USA wants to continue its policies of innovation as a global public good. The rhetoric and some of the actions that follow are meant to make clear what is in it for the USA itself and form the basis of a more transactional (tit-for-tat) approach. The private sector which is seeking to bring innovations to global markets is an important driver for presenting innovation as a global public good. Several think tanks like Brookings or ITIF repeatedly stress the importance of such an approach for US companies and government. State- and local governments often follow their own international collaboration strategies, irrespective of Washington. And the USA is known for having numerous non-government organizations that are active outside its borders. The National Academies (of Sciences, Engineering and Medicine) are promoting the concept of Open Science because they see it as essential to the progress of science and to the effective functioning of the research enterprise. And this argument extends to the mastering of advances in technologies [42]. Under this scenario, the USA thus continues to be a supporter of the concept of innovation as a global public good, if not through central government than at the very least through important stakeholder groups.

As a relative newcomer in the world of science, technology and innovation, China is still seeking its place, but seems to be determined that this should be a leading place. It has a keen eye for self-interest and is not afraid to use its powers to build on its own strengths. Since 2012 under Xi's presidency, it has actively entered the institutions of global governance and even initiated new ones. It hosted a G20 meeting in 2016 and a BRICS summit in 2017. It ratified the Paris agreement on climate change. China is aware that it needs the rest of the world. As research and innovation gradually have become more important drivers in the Chinese economy, China has increasingly become aware of the importance to build strong relations with the rest of the world, to access knowledge and experience necessary for building its own strengths and to help to create increasingly wealthy and advanced markets that may adopt innovative Chinese products and services. Its plan to modernize industry (made in China 2015) is heavily dependent on access to technologies developed in Europe and the USA. It is impossible to develop all the necessary knowledge in such a short time. This guides how China develops its international relations [43]. The Belt and Road initiative to connect (with roads, railways and seaways) east and west on the Eurasian continent confirms that China recognizes the importance of connectivity and access. ${ }^{16}$ So far, we see that China is taking a direction, which differs from that of Europe or the USA, if only because it has relatively clear goals. But in China also, with all accusations of being offensively self-interested, we see a recognition that innovation is a global public good.

\section{Scenario 3: bottom-up innovation}

The third scenario combines a few strong but diverse societal and technological tendencies, of which the 
consequences are not primarily the result of official politics and/or of large-scale programs in science and technology, although they are in several cases supported by innovation policies. This scenario is driven by the fact that in the knowledge economy new groups of actors like global companies, regions and cities and local citizens' movements are starting to play a role in innovation and in innovation politics. It results in a very dynamic landscape of global and local actions, some ad hoc, others more structural. In the end, it requires agile and attentive policies to create both opportunities and adequate regulations for such a wide diversity of innovation actions. Such policies must include an international perspective.

The bottom-up innovation scenario supposes that the strength of networking externalities, and the resulting push for globalization in many of the new technologies of today and the foreseeable future is becoming a dominant societal force. It also supposes that userdriven innovations in sustainable development, urban development, (self-)employment, and other fields will become very strong forces for change and that social networking allows global linkage and mutual strengthening of these initiatives. They have one common characteristic, which is that national policies are at the very best facilitating but in most cases, they are following. These two forces are discussed in one scenario, which is called bottom-up innovation. It combines tendencies which are primarily driven by large companies benefiting from network externalities with tendencies which are mainly driven by local idealism and activism. The first is sometimes called the Silicon Valley approach, in which technology has strong social networking components and hardly needs government involvement and regulation [44]. The second bottom-up force has an inherent distrust of strong government involvement. In early stages of their development, it is often hard to distinguish between the two. For example, the blockchain vision and technology of a trusted exchange infrastructure without intermediaries, which so far is mostly used for cryptocurrencies, started as a bottom-up development of a system without central government oversight (e.g. by the Central Banks). It is now in a stage of being picked up by big business [45]. This is not too different from how environmental activism has translated into a myriad of sustainability initiatives, some very local and small scale, but where key elements after a long process have become (almost) global (as in the $\mathrm{CO} 2$ reduction targets of the Paris Agreement on Climate Change) and are now also being picked up by big business [46].

This scenario brings a number of actors to the international policy stage which are often forgotten. We must consider, for example, the impact of the power and actions of truly global companies, which can move their assets around and are hardly dependent on a single nation's policies. In the winner-takes-all environment of the networked economy, such companies tend to become powerful political actors or consider the increasing international activities of cities and regions trying to connect their local innovation ecosystems to complementary ecosystems in other places. Here too, the most technologically advanced and economically powerful regions may become strong non-state actors. And finally, let us not forget the potential power and influence of bottom-up-driven networked innovations of which socalled sharing economy initiatives are the prime examples. A typical example is the development of mobile payment systems in remote places without a functioning banking system in Africa. The development of such systems is driven by the needs of people to easily transfer money, a few visionary entrepreneurs develop the system further and only in later stages large companies (e.g. Vodafone in Kenya) and the state step in.

All these new actors add to the complexity of the environment in which innovation diplomats work. The scenario recognizes that local politics is often better at incorporating these initiatives into their policies than national government. The vision that is behind this may turn local government into a global actor, by facilitating the exchange of experiences with similar initiatives around the world. This brings local and regional government into the domain of international relations, economic and innovation diplomacy. An increasing number of cities and regions from around the world have become active players in the international innovation arena. ${ }^{17}$ Their main goal is to strengthen the local innovation ecosystem. Building international relations is part of this. In most cases, these policy initiatives directly follow local business interests. This may include relatively new businesses (start-ups) which are the result of bottom-up processes. For example, local energy systems initiatives and urban farming businesses have an interest in internationalization, in the first place to learn from experiences elsewhere and in the second place to expand their base of operations (markets, capital, etc.).

From a theoretical perspective on innovation and innovation policy, the bottom-up innovation scenario refers to the thinking about "socialisation of innovation" as we have called it elsewhere [47] following a number of other authors. This includes concepts like user-driven innovation, democratization of innovation, massinnovation or inclusive innovation. At the very least, the practices involve opening the innovation process to wider groups of (potential) stakeholders, extensive public debate and experimentation (including Living Labs, etc.). But the real power of socialization of innovation and of the bottom-up innovation scenario lies in interest and drive of people to create something new. Idealism and 
activism are already strong drivers in themselves. But in addition, all over the world, the interest in entrepreneurship has been strongly growing over the past 10-15 years, which creates another strong driver for bottom-up innovation. Apart from fostering the support for entrepreneurship, the European Union also made "opening up the innovation process" an official policy goal in its "open innovation" approach. In the bottom-up innovation scenario, the role of government is mostly following and in a later stage possibly moving to supporting and strengthening the key actors.

\section{The scenarios and innovation systems functions}

The scenarios as discussed above help to unravel the many different targets innovation policies may pursue, including those which have direct and indirect consequences for international relations. The populism and protectionism scenario likely leads to defensive policies aiming at protecting existing structures and perceived achievements, without giving a high priority to innovation. Only countries that are leading in certain technology fields may choose for offensive innovation policies to defend their international competitive positions. The innovation as global public good scenario calls for international collaboration on all functions of the innovation system. In other words, it aims at creating an international, if not global, innovation system, for prosperity around the globe and for solving pressing societal problems. Seen in a foreign policy perspective, the bottom-up innovation scenario does not need major policy support, but it needs the right policy environment (no restrictive regulation, room for experimentation, etc.) in which bottom-up initiatives can grow and for the diffusion of such initiatives. In a true bottom-up perspective, the policies are mainly responding to needs as voiced by the communities which create and/or want to use the innovations.

In an earlier publication [5], it was proposed to use the "functions of innovation systems" scheme of Hekkert et al. [48, 49] for an analysis of innovation policies as they appear in international relations and innovation diplomacy. ${ }^{18}$ The functions are not necessarily directly related to innovation policy and its international dimensions, but they provide a very useful schematic to map potential policies. In the following Table 2 for each of the scenarios some of the potential policies for the different functions are briefly outlined. This further detailing was inspired by many publications which provide overviews and/or taxonomies of innovation policies (see for example [50, 51]). It is not a complete overview or taxonomy of potential policies but sets out the directions in which these policies may go in the context of the different scenarios. The actual policies mentioned are there as examples. The scheme helps to develop a more systematic analysis and awareness of the different policies, their direction and possible consequences. An attempt has been made to focus the account on the international dimension of the innovation system functions to prepare for a further discussion of innovation diplomacy actions in the following paragraphs.

The functions of innovation systems scheme makes it possible to distinguish between situations in which the functions are mainly state driven and policy dependent and situations in which the functions are more or less independently governed through other interactions in the system. And it makes it possible to distinguish between weak and strong presence of the functions. The scenarios as presented reflect complex mixtures of these possibilities. But overall, they reflect a move away from the generic approaches that were dominant in many western countries under the neo-classicist and neoliberal approaches during the period $1985-2010^{19}$ in the direction of more active state-roles as discussed by Mazzucato and others [52].

\section{Implications for foreign policy and diplomatic services}

Many countries ${ }^{20}$ have recognized the need to increase understanding of science-, technology- and innovationrelated issues in their foreign affairs ministries and diplomatic services and to take account of these issues in foreign policies. The National Research Council of the USA has put it like this in a strong advice to the Department of State: "The department should accelerate its efforts to engrain within the Foreign Service an appreciation of the significance of the S\&T advances taking place at home and abroad. It needs to support more fully our front-line diplomats with strong contingents of civil servants who are up-to-date on the technical dimensions of numerous issues on the department's agenda. Also, it should increase the cadre of Foreign Service Officers (FSOs) with technical backgrounds and provide increased training and education for all FSOs to prepare them for handling S\&T-related issues, including assignments to positions that focus on S\&T issues" ([53], p., 2). Increasing knowledge and understanding within the services is important, but by far not enough. In the new world in which the three scenarios outlined above might very well develop at the same time (albeit with differing weight in different nations, depending on the actual political constellation), political guidance of the foreign services is becoming more important.

In the recent past, internationalization and collaboration were the widely accepted trends. It led to quite clear roles for the foreign diplomatic services in relation to science, technology and innovation, as they were outlined for example in the Nesta advice to the UK innovation diplomats [54]. With a focus on establishing 
Table 2 Innovation system functions (based on the work of Hekkert et al. [48]) in the different scenarios

\begin{tabular}{|c|c|c|c|}
\hline Functions & Populism and protectionism & Innovation as global public good & Bottom-up innovation \\
\hline 1. Entrepreneurial discovery & $\begin{array}{l}\text { - Strong focus on national industry } \\
\text { capabilities and collaboration } \\
\text { - Protective/defensive against foreign } \\
\text { attacks on IPR, markets, human } \\
\text { resources, etc. }\end{array}$ & $\begin{array}{l}\text { - Develop international value networks } \\
\text { - Develop strong localized ecosystems } \\
\text { in international context }\end{array}$ & $\begin{array}{l}\text { - Focus on entrepreneurship } \\
\text { - Learning by doing/using } \\
\text { - Generic ecosystem-oriented } \\
\text { policies } \\
\text { - Local needs and initiatives } \\
\text { - Activism }\end{array}$ \\
\hline 2. Knowledge development & $\begin{array}{l}\text { - Not a high priority } \\
\text { - Training/skills in existing industries }\end{array}$ & $\begin{array}{l}\text { - Strengthening "open science" and } \\
\text { international collaborative programs } \\
\text { - Seeking complementarities }\end{array}$ & $\begin{array}{l}\text { - Broad science and technology } \\
\text { education }\end{array}$ \\
\hline $\begin{array}{l}\text { 3. Knowledge diffusion } \\
\text { (networks) }\end{array}$ & $\begin{array}{l}\text { - Support for diffusion in national } \\
\text { industries } \\
\text { - Seeking international collaboration } \\
\text { only in function of national strengths }\end{array}$ & $\begin{array}{l}\text { - Exchange programs } \\
\text { - Sharing IPR etc. in collaborative } \\
\text { ventures }\end{array}$ & $\begin{array}{l}\text { - Business led diffusion in sectoral } \\
\text { or regional ecosystems } \\
\text { - International diffusion in function } \\
\text { of building markets }\end{array}$ \\
\hline $\begin{array}{l}\text { 4. Guidance of the search } \\
\text { (role of national priority } \\
\text { setting) }\end{array}$ & $\begin{array}{l}\text { - Nationally defined and supported } \\
\text { missions } \\
\text { - International intelligence }\end{array}$ & $\begin{array}{l}\text { - Focus on global challenges } \\
\text { thinking } \\
\text { - Benchmark international } \\
\text { competitiveness }\end{array}$ & - No strong guidance \\
\hline 5. Market formation & $\begin{array}{l}\text { - Transactional approach to international } \\
\text { access to markets } \\
\text { - Self-interest guides taxation, regulation } \\
\text { and standards } \\
\text { - Nationally oriented public procurement }\end{array}$ & $\begin{array}{l}\text { - Global public and public/private } \\
\text { initiatives } \\
\text { - Work towards a global "level- } \\
\text { playing-field" in business led } \\
\text { innovation }\end{array}$ & $\begin{array}{l}\text { - Business led and user-led } \\
\text { - Allow for experimentation } \\
\text { - Allow new models (e.g. sharing, } \\
\text { buy local) } \\
\text { - Focus on international market } \\
\text { access }\end{array}$ \\
\hline $\begin{array}{l}\text { 6. Resources mobilization } \\
\text { (budgets, finance) }\end{array}$ & $\begin{array}{l}\text { - Likely decline } \\
\text { - Entirely driven by national interests } \\
\text { and policy goals }\end{array}$ & $\begin{array}{l}\text { - International collaboration and } \\
\text { pooling of resources } \\
\text { - Strengthening of global } \\
\text { governance institutions }\end{array}$ & $\begin{array}{l}\text { - No strong national or } \\
\text { international directive resources } \\
\text { policies } \\
\text { - Generic human capital strategies }\end{array}$ \\
\hline $\begin{array}{l}\text { 7. Creation of legitimacy; } \\
\text { fighting resistance to change }\end{array}$ & $\begin{array}{l}\text { - May range from anti-innovation } \\
\text { attitude (reduced innovation policy } \\
\text { actions) to aggressive national interest } \\
\text { strategy }\end{array}$ & $\begin{array}{l}\text { - Building support for global } \\
\text { challenges } \\
\text { - Spreading innovation thinking and } \\
\text { behaviour (including values and } \\
\text { policies) }\end{array}$ & $\begin{array}{l}\text { - Business led (policy focus on } \\
\text { boundary conditions) } \\
\text { - Actions related to opening } \\
\text { markets } \\
\text { - Support socialization }\end{array}$ \\
\hline
\end{tabular}

(mutually) beneficial collaborative relations, Nesta distinguishes the following four roles: (a) exploring and informing about opportunities, (b) influencing and promoting policies to improve conditions for collaborating, (c) cultivating the new international partnerships and connecting the stakeholders and (d) activating the resources and scaling promising collaborations. Whatever the mix of our scenarios in the real world may look like, it is safe to conclude that these four roles of innovation diplomats will remain important. But in the highly competitive environment of today, in which there is additionally an increasing number of non-state actors pursuing their self-interest by directly or indirectly trying to exert political influence, collaboration is no longer the only goal innovation diplomats should take care of. They will be confronted with a growing number of apparently contradictory demands such as company interests vs. national interests, economic growth vs. innovation, defensive and offensive competitive strategies, and protectionism vs. openness. ${ }^{21}$ Without political guidance, the diplomatic services will soon have to reduce their activities to the first of the four roles which Nesta discerns: exploring and informing. Any action under one of the other roles may easily run into legitimacy problems.
When the three scenarios coexist, as is currently the case in many countries around the world, two highly demanding steps are needed to develop a clear foreign policy view on innovation and a clear set of guidelines for innovation diplomats. The first is what is often called a "whole-of-government-approach". The point here is to address the linkages between science, technology and innovation and other policy areas, such as trade, education, social affairs, health and environment. The linkages need to be understood as going in two directions, from science, technology and innovation to the other policy areas and reverse. The second step, called "whole-of-society-approach", is pushing this even further. ${ }^{22}$ It is necessary because today's society is full of relatively independent actors, which all may have their own connections with politics and policymaking in other countries (e.g. large companies) or with powerful stakeholder groups in these countries (e.g. environmental movements). In other words, alignment is necessary within government and within society as a whole to build a foreign innovation policy vision which guides the activities of the innovation diplomats. Identifying and agreeing on the policy goals that support this vision is a necessary 
condition to be able to build effective coordinated and linked policies and actions.

These policy goals should not only build on a view on collaboration in science, technology and innovation. Especially when it comes to technology and innovation, but increasingly also for those fields of science which directly drive technological advances and innovation in products, services and systems, very complex patterns of competition and collaboration are likely to develop. These patterns need to be supported, or-if politics says so-need to be changed by foreign innovation policy. The tasks of the innovation diplomats thus are going to include more awareness, more intelligence and more actions in relation to competitiveness. In line with the innovation as global public good scenario, the focus must be on identification of policies and regulations which prevent a level playing field in competition and market access by imposing restrictions or demands on innovation. And it should be on developing meaningful diplomatic actions against such behaviour. ${ }^{23}$ The populism and protectionism scenario may lead to policies which do exactly the reverse: develop regulatory barriers against identified or perceived competitive threats. Only countries which have a sufficient economic (or military) powerbase may try to develop a transactional approach to fight competition. The bottom-up innovation scenario has gained importance quite rapidly over the past decades in which neo-liberal thinking dominated innovation policy development. The innovation diplomacy services have been very good at ad hoc and on demand support for internationalization to a wide diversity of innovation actors in the recent past. ${ }^{24}$ In the case of large companies, the problem arises that the diversity of their policy relations in other countries is difficult to handle for limited capacity diplomatic services. In all important countries, be it for production or for markets, such companies have representations with their own direct government contacts. And increasingly governments announce that they have special contact points for such companies (for example, as France announced for Facebook and Amazon). This makes alignment easy in organizational terms, but it does not rule out wide differences in interests between the company and national policy. Less well-organized actors (for example new technology-based start-ups seeking partners to access foreign markets) will require a major effort of the diplomatic services, not in the very least because many of them want to present their product or service from the start in a larger number of countries, if not globally.

\section{Conclusions: towards a vision for European innovation diplomacy}

Europe has a history of searching for the elements which should define its international and global role, both as a general political power as well as specifically in the field of science, technology and innovation. This search can be found in several different vision and scenario documents, from the European Commission, from EU funded research consortia, from interest organizations and from think tanks. ${ }^{25}$ The vision document of the current European Commission shows that at present Europe's starting point is firmly anchored in the "innovation as global public good" scenario: "Fostering international cooperation in research and innovation is a strategic priority for the European Union so that we can access the latest knowledge and the best talent worldwide, tackle global societal challenges more effectively, create business opportunities in new and emerging markets, and use science diplomacy as an influential instrument of external policy" ([55], p., 1).

Is such a strategy good enough when it is, for example, confronted with the Chinese strategies of technological leadership on the one hand and the Belt and Road initiative $^{26}$ on the other? Or with the international strategy of the USA, which seems to go in the direction of a pragmatic transactional approach? Is it strong enough to face populist and nationalist tendencies within the Union itself and elsewhere in the world? And is it strong enough to provide a framework in which bottom-up innovation can flourish?

It can be, but only if it is matched by a set of other policies that address issues related to the changing characteristics of competition in the international arena and that address issues brought forward by the populist and nationalist movements. The following outlines a few starting points or policy directions that Europe should follow in its international innovation policies and which must guide its diplomatic actions. These points are not new, on the contrary, some are strongly present in European external policies for quite some time, but in a rather disconnected way.

1. To start with, Europe should continue to foster, maintain and spread the message of open science, open innovation and remain open to the world. It clearly outlines the intentions and directions of Europe when it enters the international or global arena: Europe is seeking open collaboration to the benefit of all participants, taking international solidarity and the perspective of innovation as a global public good as its starting point. This starting point needs to be complemented with at least three other policy initiatives.

2. Europe should increase efforts to create a global level playing field, including free trade, free exchange of knowledge and innovative products and services. Part of this is to take care of reciprocity in exchanging information, technology and innovations. 
There might be good reasons to transfer technology under favourable conditions to developing and/or partner countries, but potential consequences in the home market may justify regulation of such transfers and the setting of limits on the freedom of companies to move their (technology) assets to other countries. In the same vain, the development and implementation of Europe's "Open Science Cloud" (facilitating the exchange of data and research tools) must include measures which regulate collaboration with global partners [56].

3. In the third place, it is necessary to identify and increase awareness of Europe's technological and related business strengths and in how far such strengths are critical for the functioning of Europe's economy and society. Europe represents a large and wealthy market, has a strong and innovative industry, which delivers high quality products and services, and has several strong innovation ecosystems. Fostering such strengths and critical technologies ${ }^{27}$ is necessary to maintain a strong negotiating position in a world in which a major player like the USA is moving towards a transactional approach to international relations. The actual policies may be both defensive as well as offensive. The intention of this third policy approach is to add a position of power to Europe's international relations and negotiations.

4. The fourth and final group of complementary policies should focus on identifying and spreading the key social values and goals (e.g. in relation to quality of life, quality of labour, culture including privacy, and sustainability) that Europe wants to pursue in its internal and external innovation policies. Such values and goals can partly be spread to other countries via collaborative activities such as in the case of the transfer of European thinking about innovation ecosystems and the related smart specialization strategies. International collaboration might also be the preferred mechanism to regulate the social impacts of the platform economy business, but one-sided action could be just as effective, as the recent example of GDPR (General Data Protection Regulation) shows. In this case, Europe's example sets a standard, which finds many global followers. There are also cases where some form of force has been used, such as when Bangladesh was exempted from preferential trade arrangements with the USA and Europe, to force the country to rapidly modernize the labour conditions in its textile industries. The societal goals that will drive future European research and innovation missions, together with the UN Sustainable Development Goals [57], will be very good starting points to invite other countries to join these missions and pursue similar societal goals.

It is important to bring these policy directions together in a coherent framework to present a clear futureoriented vision of what Europe sees as its international role in innovation. With such a vision and the supporting policies, the role of Europe on the global platform gains in visibility and strength. The Union's external actions and the foreign and diplomatic services of the member states can become more effective when an improvement in the alignment in the field of external innovation policies between Member States, key business, other stakeholders and the Union is achieved. Such an action was already proposed by vice-president Kaitanen in 2016 [58] considering the broader field of economic diplomacy. But according to a Clingendael policy brief [59], "EU member state governments and privatesector organizations have barely discussed the issue partly because they remain largely unaware of the increasing EU activism and/ or because they do not wish to encourage it." Over the past 2 years, the interest has grown, not in the least because the Trump administration changed the international economic policy environment. Hopefully, this wake-up call enables the development of a shared and coherent framework and coordinated action in Europe. The complexities of applying these points both within and outside the European Union are fully acknowledged. It will be a challenge to align the Member States and an even greater challenge to apply the proposed points as policy directions in the international and global environment. But having such a set of policy directions will also provide the necessary policy guidance to foreign affairs services and to innovation diplomacy.

\section{Postscript: science diplomacy and innovation diplomacy} Throughout this paper, it was argued that issues of innovation and competition have gained prominence over the collaboration orientation of science diplomacy. With innovation, science has also become an issue in the competitive relations between nations. This raises the question if there is still room for a view of science as a relatively neutral and authoritative function in society and if there is a special role for scientists in international relations. In other words, is it possible and useful to distinguish between science diplomacy and innovation diplomacy? In the case of innovation diplomacy, the diplomatic activities are clearly there to push science, technology and innovation forward, in the national interest or (as in the case of innovation as global public good) in the international or global interest. It is "diplomacy for science" (and innovation can be added here) in the 
terminology of the Royal Society and the AAAS [60]. But what can science do for diplomacy? In line with the "science for diplomacy" thinking, Berkman [3] stresses the independent role of science and scientists: "Science is a neutral platform that allows for less politically charged dialogues, which in turn create bridges that help overall diplomatic efforts." The classical example which supports this view is the Intergovernmental Panel on Climate Change (IPCC). Berkman also mentions international Arctic scientific collaboration and SESAME, the Middle East's first major international research centre, designed to host both Israeli and Palestinian scientists. Although the conditions for such efforts, which usually take many years to show any political impact as the case of the IPCC illustrates [46], are not getting better under the influence of growing competition, nationalism and populism, they remain valuable. In the perspective of responsible science and responsible scientists, the efforts to jointly develop scientific insights about shared problems and common views on international policy actions should be welcomed. The world of science should, wherever possible, take collaborative action to build such insights and policy views on the many issues which transcend national boundaries (like was done in the case of nanotechnology and should be done in the case of Artificial Intelligence). The UN sustainable development goals provide a good, but by far not the only starting point. The tensions that will arise between the two approaches (neutral and independent science diplomacy and competition-oriented innovation diplomacy) might very well be turned into socially productive insights and actions (see for example [61]).

\section{Endnotes}

1“... the largest surplus for international trade in goods and services was recorded by the EU $(+€ 304$ billion in 2016) ahead of China ( $€ 226$ billion), while the United States had the largest deficit ( $€ 456$ billion)." [62]

${ }^{2}$ It builds further on an earlier publication [5] which outlined some of the basic questions and methodological issues. Other publications resulting from the EL-CSID project address issues of science and culture in international relations and diplomacy.

${ }^{3}$ This paragraph partly builds on unpublished work done in the CHIST-ERA Foresight Advisory Board in 2015.

${ }^{4}$ Stating that the capacity of computer chips doubles and the costs halve about every 2 years.

${ }^{5}$ This does not mean that such virtual monopolies are uncontested. For example, Google's search engine took over from Altavista around the year 2000 and Amazon might soon see its position threatened by Chinese Alibaba.
${ }^{6}$ For an extensive discussion of the different policy strategies see [63].

${ }^{7}$ This is documented in a working paper focusing on the analysis of specific innovation capabilities-oriented collaboration programs [25].

${ }^{8}$ See for example the case of Fraunhofer establishing a research centre in Chile (http://www.fraunhofer.cl/).

${ }^{9}$ See for instance the works of authors like Michael Porter, Jane Jacobs and Richard Florida.

${ }^{10}$ For an overview see for example [47].

${ }^{11}$ See for example [33, 64].

${ }^{12}$ The Information Technology and Innovation Foundation (ITIF) is an US-based independent public policy think-tank focusing on accelerating innovation.

${ }^{13}$ This is not always the case. Large countries with ample resources may choose to follow a more offensive strategy, as the example of the Chinese technology strategy illustrates (see for example [65].

${ }^{14}$ For several years now, ITIF makes an almost annual and worldwide overview of protective policy measures that work as barriers against innovation, see [66] for the latest edition.

${ }^{15}$ In line with scenario 1 , growing nationalism weakens the support for these organizations, but the pressures to deliver on specific topics have increased. In a fragmented world, multilateral solutions might prevail. The diplomatic work to build such efforts, however, is likely to become more sensitive to the wider foreign policy environment (e.g. geopolitical powerplay). In other words, all international efforts will be viewed and judged in the context of nationalist strategies.

${ }^{16}$ Despite a general reluctance from the European side, "The European Commission and the Chinese government also signed a Memorandum of Understanding on the EU-China Connectivity Platform to enhance synergies between China's "One Belt One Road" initiative and the EU's connectivity initiatives such as the TransEuropean Transport Network policy. The Platform will promote cooperation in areas such as infrastructure, equipment, technologies and standards. This will create multiple business opportunities and promote employment, growth and development for both sides, and it will be done in cooperation with the EIB." [67]

${ }^{17}$ For example, Brainport Development (representing the interests of the Eindhoven region in the Netherlands) states explicitly that it wishes to strengthen the position of the region in Dutch economic diplomacy, including its relations with the Ministries of Foreign and Economic Affairs and the economic representations in other countries around the world. According to Brainport Development, this includes also visiting attractive partners in for example Taipei (Taiwan) and Waterloo (Canada) to ease access to China and the US and to ease reverse access to the European market. These and other 
international activities are institutionalized in the Brainport International Programme [68].

${ }^{18}$ The innovation systems functions relate to all the policy instruments that, for example, can be found in the taxonomies mentioned below. Several functions involve instruments of direct or indirect financial support (e.g. for knowledge development, knowledge diffusion or market formation through mechanisms such as procurement and taxation), others involve stimulating networking, strengthening eco-systems, etc., and a few functions relate to the potential role of government in guiding the search for innovations through national priority setting and/or organizing stakeholder consent and through maintaining ethical and technical standards and regulations.

${ }^{19}$ For a discussion see for example [69].

${ }^{20}$ See some examples discussed in [5].

${ }^{21}$ The solar panels story (see the case study [18]), for example, led to contradictory demands on the European Commission, with the building and installation sector being against import taxes (which would raise their costs) and the few remaining European producers of solar panels being in favour.

${ }^{22}$ Both concepts, "whole of government" and "whole of society" have been used in international organizations like OECD, World Health Organization and UN to address the increasingly interlinked complexities when making policies work.

${ }^{23}$ The work of the US-based Information Technology and Innovation Foundation provides good examples of this approach $[21,66]$.

${ }^{24}$ This is mainly based on their service offerings on the Web and on personal experience.

${ }^{25} \mathrm{An}$ abundance of such documents can easily be found online (see for example [55, 70]).

${ }^{26}$ Even when the Belt and Road initiative lacks systematic translation into Chinese policy, it convinces other actors, including the European Commission, to consider taking action.

${ }^{27}$ Due to the dominance of the neo-liberal economic policy vision and the related generic innovation policies, thinking about existing and needed technological strengths is of recent date in Europe. An example can be found in [71].

\footnotetext{
Abbreviations

AAAS: American Association for the Advancement of Science; ALCUE Net: Latin America, Caribbean and European Union - Net; AL-Invest: América Latina - Invest; BRICS: Brazil, Russia, India, China, South-Africa; CELAC: Community of Latin American and Caribbean States; EIB: European Investment Bank; EIRMA: European Industrial Research Management Association; ELAN: European and Latin America technology-based business Network; EL-CSID: European Leadership in Cultural, Science and Innovation Diplomacy; FSO: Foreign service officers; GDP: Gross domestic product; ICT: Information and communication technology; ILO: International Labour Organization; INCO: International Cooperation (EU); IPCC: Intergovernmental Panel on Climate Change; IPR: Intellectual Property Rights; ITIF: Information Technology and Innovation Foundation; LAC: Latin America and the
}

Caribbean; LAIF: Latin America Investment Facility; OECD: Organization for Economic Cooperation and Development; PV: Photovoltaic; R\&D: Research and development; S\&T: Science and technology; SESAME: International Centre for Synchrotron-Light for Experimental Science and Applications in the Middle East; STI: Science, Technology and Innovation; UN: United Nations; WTO: World Trade Organization

\section{Acknowledgements}

This paper has benefited from the comments of JIIP colleagues, from the discussions with partners in the EL-CSID project, from comments of and discussions with a group of about 20 experts in a workshop, held in Brussels on 4 October 2018 and from to-the-point advice of two anonymous reviewers.

\section{About the author}

Jos Leijten is senior policy advisor and former director of the Joint Institute for Innovation Policy. He held management positions in innovation policy research in the Netherlands Organization for Applied Scientific Research TNO. He studied urban and regional planning at the Radboud University of Nijmegen (1975) and received his PhD from the Free University of Amsterdam in 1991 for a thesis on technology assessment and policy.

\section{Funding}

This project has received funding from the European Union's Horizon 2020 research and innovation programme under grant agreement No 693799.

\section{Availability of data and materials}

There are no specific datasets analysed or generated during the study.

\section{Authors' contributions}

$J$ is the author of this paper. All quotations of others are referenced. The author read and approved the final manuscript.

\section{Ethics approval and consent to participate}

Not applicable.

\section{Consent for publication \\ Author agrees to publish.}

\section{Competing interests}

The author declare no competing interests. A short text which partly summarizes this paper is published as a Policy Brief on the EL-CSID project website.

\section{Publisher's Note}

Springer Nature remains neutral with regard to jurisdictional claims in published maps and institutional affiliations.

Received: 22 January 2019 Accepted: 21 May 2019

Published online: 20 June 2019

\section{References}

1. Ortiz-Ospina E and Roser M (2018) International trade [Online]. Available: https://ourworldindata.org/trade-and-globalization. Accessed 15 June 2018.

2. Lund S, Tyson L (2018) Foreign Affairs, Globalisation is not in retreat, vol 97, p 3.

3. Berkman PA (2018) Could science diplomacy be the key to stabilizing international relations? 2018 [Online] Available: https://theconversation.com/ could-science-diplomacy-be-the-key-to-stabilizing-international-relations87836. Accessed 6 July 2018

4. OECD (2018) OECD innovation strategy [Online] Available: https://www. oecd.org/site/innovationstrategy/defininginnovation.htm. Accessed 18 June 2018.

5. Leijten J (2017) Exploring the future of innovation diplomacy. Eur J Futur Res 5:20.

6. Bound K (2016) Innovating together? The age of innovation diplomacy. In: The global innovation index 2016: Winning with global innovation. Ithaca Fontainebleau Geneva Cornell University INSEAD WIPO, pp 91-95.

7. World Economic Forum (2015) Deep shift; technology tipping points and societal impact. Global Agenda Council on the Future of Software \& Society, Geneva 
8. IEEE (2014) The future we deserve, IEEE Spectrum, 50th anniversary issue, pp 1964-2014.

9. Borrus M, Zysman J (1997) Wintelism and the changing terms of global competition: prototype of the future? Berkely round table on the international economy February.

10. Scott M (2018) Forget 'techlash' - the biggest problem for tech is a widening transatlantic rift. 17062018 [Online] Available: https://www. politico.eu/article/europe-us-tech-techclash-tax-competition-data-protectionvestager/. Accessed 21 June 2018.

11. Lynskey O (2017) Regulating platform power. LSE law, society and economy working papers 1 London.

12. EuroStemCell (2018) Regulation of stem cell research in Europe [Online] Available: https://www.eurostemcell.org/regulation-stem-cell-researcheurope. Accessed 3 July 2018.

13. Hogart I (2018) Al Nationalism. 13062018 [Online] Available: https://www. ianhogarth.com/blog/2018/6/13/ai-nationalism. Accessed 22 June 2018.

14. Kritikos M (2018) What if blockchain were to be truly decentralised? 2709 2018 [Online] Available: https://epthinktank.eu/2018/09/28/what-ifblockchain-were-to-be-truly-decentralised-scientific-and-technologypodcast/. Accessed 16 Oct 2018.

15. Kinkel S (2015) Setting the scene: global value chains, re-shoring activities, global innovation networks, and their impact on global innovation platforms. In: Can Policy Follow the Dynamics of Global Innovation Platforms? Delft 6CP, pp 15-40.

16. Trinomics, DNV-GL, PricewaterhouseCoopers, JIIP (2016) Assessment of Photovoltaics - Study Carried out on Behalf of the European Commission DG RTD Task A: Current State - Final Report European Commission, Luxumburg.

17. Trinomics, DNV-GL, PricewaterhouseCoopers, JIIP (2016) Assessment of photovoltaics - study carried out on behalf of the European Commission DG RTD task C: historical review of EU decline - final report. European Commission, Luxemburg.

18. Gehrt D (2018) Case Study Report: EU-China S\&T cooperation in the field of solar PV, EL-CSID Working Paper 15, Brussels.

19. Brehm Christensen M, Clancy E (2018) Exposed: Apple's Golden Delicious Tax Deals. Is Ireland helping Apple pay less than 1\% tax in the EU? GUE/ NGL Brussels.

20. Freeman C (1987) Technology policy and economic performance: lessons from Japan. Pinter Pub. Ltd, London.

21. Atkinson RD, Ezell SJ (2013) Building the global innovation economy, The Futurist, pp 14-19 January-February.

22. Rieffel $L$ (2018) Institutions are under existential threat, globally. 28 June 2018 [Online] Available: https://www.brookings.edu/blog/up-front/2018/06/ 28/global-institutions-are-under-existential-threat/. Accessed 13 July 2018.

23. European Commission (2018) International Cooperation and Development [Online] Available: https://ec.europa.eu/europeaid/general_en. Accessed 10 July 2018.

24. OECD (2014) New EU development cooperation strategies in Latin America and the Caribbean, OECD, Paris.

25. Sanchez B, Arrizabalaga E, Mendibil J (2018) New Horizons shaping science, technology and innovation diplomacy: the case of Latin America and the Caribbean and the European Union. EL-CSID Working Paper 20, Brussels.

26. Selleslaghs J (2017) EU-Latin America science diplomacy. EL-CSID Working Paper 8, Brussels.

27. Daimler $S$ et al (2015) Forward visions on the European research area (VERA). FHG-ISI Karlsruhe 2015.

28. Ricci A Sessa C and Weber M (2017) New horizons: future scenarios for Research \& Innovation Policy in Europe (BOHEMIA). European Commission Brussels.

29. Elsevier (2019) Research futures: drivers and scenarios for the next decade. Elsevier.

30. Erdmann L, Schirrmeister E (2017) Constructing transformative scenarios for research and innovation futures. Foresight 18(3):238-252.

31. Altbach PG, de Wit $\mathrm{H}$ (2018) Are we facing a fundamental challenge to higher education internationalisation? International Higher Education number 93, pp 2-4 Spring.

32. Atkinson RD Castro D, McQuinn A (2015) How tech populism is undermining innovation. Information Technology \& Innovation Foundation, Washington DC.

33. Rodrik D (2018) Populism and the economics of globalisation. Journal of Intl Bus Pol 1(1-2):12-33.
34. Overheid.nl (2017) Handelingen Tweede Kamer der Staten Generaal 2806 2016-2017. [Online] Available: https://zoek.officielebekendmakingen.nl/h-tk20162017-93-9.html. Accessed 18 July 2018.

35. Posen AS (2018) How trump is repelling foreign investment. The long-term costs of economic nationalism. 23 July 2018 [Online] Foreign Affairs. Accessed 03 Apr 2019.

36. Frederic S. Pardee school of global studies (2017) Berger: Trump's foreign policy likely to be transactional. 17 January 2017 [Online] Available: https:// www.bu.edu/pardeeschool/2017/01/24/berger-trumps-foreign-policy-likelyto-be-transactional/. Accessed 14 Aug 2018.

37. Stiglitz J (1999) Knowledge as a global public good. In: Global public goods UNDP, New York, pp 308-325.

38. Tran M (2011) Philanthropic foundations bring new challenges to aid debate. The Guardian [Online] Available: https://www.theguardian.com/ global-development/2011/nov/09/philanthropic-giving-challenge-aiddebate. Accessed 30 July 2018.

39. BBC News (2018) Google's loon brings internet-by-balloon to Kenya. 1907 2018 [Online] Available: https://www.bbc.com/news/technology-44886803. Accessed 30 July 2018

40. European Commission (2018) Goals of research and innovation policy. [Online] Available: https://ec.europa.eu/info/research-and-innovation/ strategy/goals-research-and-innovation-policy_en. Accessed 08 Aug 2018.

41. European Union (2017) European Union global strategy. 20122017 [Online] Available: https://europa.eu/globalstrategy/en/news. Accessed 13 Aug 2018.

42. National Academies of Sciences, Engineering, and Medicine (2018) Open Science by design: realizing a vision for 21st century research. The National Academies Press, Washington DC.

43. Wúbbeke J, Meissner M, Zenglein MJ, Ives J, Conrad B (2016) Made in China 2025. The making of a high-tech superpower and consequences for industrial countries. MERICS, Berlin.

44. McAfee A, Brynjolfsson E (2017) Machine, platform, crowd: harnessing our digital future. W. W. Norton \& Company, New York.

45. Spencer MK (2018) Ethereum ETH Blockchain ready for second phase in Q4 2018. [Online] Available: https://medium.com/futuresin/ethereum-ethblockchain-ready-for-second-phase-in-q4-2018-50189b799a7e. Accessed 18 July 2018.

46. Montalvo C, Leijten J (2015) Is the response to the climate change and energy challenge a model for the societal challenges approach to innovation. Intereconomics 50(1):4-30 C pproach to innovation," Intereconomics, vol. 50, no. 1, pp. 4-30, January/February 2015.

47. Leijten J, Loikkanen $T$ (2016) Forty years of innovation policy research lessons and outlook. In: Leijten J (ed) What would Walter say? The Hague 6CP, pp 15-56.

48. Hekkert M (2010) The challenge of sustainable innovation policy. In: Elg L, Leijten J (eds) New economic ground for innovation policy 6CP Bilbao.

49. Hekkert $M$ et al (2007) Functions of innovation systems: a new approach for analysing technological change. Technol Forecast Soc Chang 74(4):413-432.

50. Edler J, Fagerberg J (2017) Innovation policy: what, why, and how. Oxf Rev Econ Policy 33(1):2-23.

51. EC-OECD (2018) STI policy taxonomy / ontology STIP monitoring and analysis (EC-OECD project). [Online] Available: https://www. innovationpolicyplatform.org/stip-monitoring-and-analysis/sti-policytaxonomy-ontology. Accessed 28 Aug 2018.

52. Mazzucato M (2018) The entrepreneurial state. Debunking public vs private sector myths. Penguin, London.

53. National Research Council (2015) Diplomacy for the 21st century: embedding a culture of science and technology throughout the Department of State. National Academies Press, Washington DC.

54. Nesta (2015) Innovation policy toolkit: tradecraft for innovation diplomats. Nesta, London.

55. European Commission (2016) Open innovation, open science, open innovation - a vision for Europe. European Union Brussels.

56. Science/Business Network (2018) Priorities for the European Open Science Cloud [Online] Available: https://sciencebusiness.net/sciencecloud/news/how-will-europes-science-cloud-fit-global-research-scene. Accessed 31 Oct 2018.

57. UN Department of Social and Economic Affairs (2018) Sustainable development knowledge platform [Online] Available: https:// sustainabledevelopment.un.org/. Accessed 27 July 2018.

58. European Commission (2016) Vice-President Katainen's speech "Prosperity and Economic Diplomacy" at the EPSC seminar [Online] Available: https:// 
ec.europa.eu/commission/commissioners/2014-2019/katainen/ announcements/vice-president-katainens-speech-prosperity-and-economicdiplomacy-epsc-seminar_en. Accessed 4 Sept 2018.

59. Okano-Heijmans M, Saverio Montessano F (2016) Who is afraid of European economic diplomacy? Clingendael Policy Brief.

60. Royal Society and American Association for the Advancement of Science (2010) New Frontiers of science diplomacy, London.

61. Tatalovic M (2018) Academies join forces in fight back against policymakers ignoring scientific evidence. [Online] Available: https://sciencebusiness.net/ news/academies-join-forces-fight-back-against-policymakers-ignoringscientific-evidence. Accessed 31 Aug 2018

62. DESTATIS Statistisches Bundesambt (2018) Trade with goods and services: EU has worldwide largest export surplus.[Online] Available: https://ec. europa.eu/eurostat/statistics-explained/index.php/The_EU_in_the_world_-_ international trade. Accessed 6 Dec 2018.

63. Cimoli M, Dosi G, Stiglitz JE (2009) Industrial policy and development. The political economy of capabilities accumulation. Oxford University Press, Oxford.

64. Meyer H (ed) (2017) Understanding the populist revolt. Social Europe

65. People's republic of China state council (2015) made in China 2025, Beijing.

66. Cory N (2018) The worst innovation mercantilist policies from 2017. ITIF, Washington DC

67. European Commission (2015) Investment plan for Europe goes global: China announces its contribution to \#investEU. European Commission Press release Database [Online]. Available: http://europa.eu/rapid/press-release_IP15-5723_en.htm. Accessed 14 Aug 2018.

68. Brainport Eindhoven (2018) Join Europe's leading innovative top technology region. [Online] Available: https://brainporteindhoven.com. Accessed 16 Aug 2018.

69. Elg L and Leijten J (2010) New economic ground for innovation policy. Bilbao CultivaLibros.

70. ESPAS (2015) Global trends to 2030: can Europe meet the challenges ahead? [Online] Available: https://ec.europa.eu/epsc/sites/epsc/files/espasreport-2015.pdf. Accessed 24 Apr 2019.

71. Reiss T et al (2016) Study on EU positioning: an analysis of the international positioning of the EU using revealed comparative advantages and the control of key technologies, European Commission Brussels.

\section{Submit your manuscript to a SpringerOpen ${ }^{\circ}$ journal and benefit from:}

- Convenient online submission

- Rigorous peer review

- Open access: articles freely available online

- High visibility within the field

- Retaining the copyright to your article

Submit your next manuscript at $\boldsymbol{\nabla}$ springeropen.com 